\title{
Alpha-Lipoic Acid and N-Acetyl Cysteine Ameliorates Oxidative Stress and Hepatic Injury in Alloxan-Induced Diabetic Rabbits
}

\author{
Omar H M ${ }^{1, *}$, Saad El-dien H. M. ${ }^{2}$, Saeed M A ${ }^{1}$, Al-Salahy M. B. ${ }^{1}$, Abel-Tawab H. S. ${ }^{1}$ \\ ${ }^{1}$ Zoology Department, Faculty of Science, Assiut University, Assiut, 71516, Egypt \\ ${ }^{2}$ Histology Department, Faculty of Medicine- Assiut University, Assiut, 71516, Egypt
}

\begin{abstract}
Insulin dependent diabetes mellitus is a chronic metabolic disorder that continues to present a major worldwide health problem. It characterized by high level of glucose in blood due to deficiency of insulin. Generation of ROS is thought to mediate the cytotoxic action of alloxan on the pancreatic ß-cell and play an important role in the complication of diabetes. The aim of the present work to evaluate the efficacy of antioxidant $\alpha$-lipoic acid and N-acetylcysteine to ameliorate the oxidative stress in hepatic tissue that induced by alloxan treatment in rabbits. Thirty-two male white rabbits were used in the present study classified into four groups. Group worked as normal control group, $2^{\text {nd }}$ worked as untreated diabetic rabbits, $3^{\text {rd }}$ and $4^{\text {th }}$ groups diabetic rabbits treated with $\alpha$-lipoic acid and $\mathrm{N}$-acetyl cysteine respectively. Diabetic rabbits showed weigh loss, increase in relative liver weight, plasma glucose level and ALT activity. Also, showed morphological changes in the liver with increased in LPO, NO, CP and DNA fragmentation \% and alteration in the non-enzymatic antioxidant levels (Vit E and GSH) and enzymatic antioxidant activities (CAT, SOD, GPx, GR, GGT, and GST) compared to control. Treatment of diabetic rabbits with either $\alpha$-lipoic acid or $\mathrm{N}$-acetyl cysteine overcome the loss of body weight gain and normalized relative liver weight, plasma glucose and ALT activity. Moreover, treatment improves the oxidative tress parameters and morphological changes that induced by alloxan and hyperglycemia. Conclusion: oxidative stress in alloxan induced diabetic rabbits plays a crucial role in hepatic degenerative changes. Treatment of diabetic rabbits with $\alpha$ lipoic acid or $\mathrm{N}$-acetyl cysteine caused normoglycemia and liver cell reprogramming due to its antioxidant activities. Beneficial action seems to result mainly from direct scavenging of ROS and restoring GSH redox state.
\end{abstract}

Keywords Diabetes, Alloxan, A Lipoic Acid, N-Acetyl Cysteine, Oxidative Stress, Liver and Rabbits

\section{Introduction}

Alloxan the best known B-cell toxin, inside the cells, its central carbonyl is reduced by cellular thiols into dialuric acid and generate superoxide, hydrogen peroxide and hydroxyl radical[1]. This oxidative decomposition of dialuric acid is thought to account for alloxan toxicity in the B-cell, which has low levels of superoxide dismutase and glutathione[2].Generation of ROS also, plays an important role in the etiology of diabetic complications. Under diabetic conditions, ROS are produced via glucose autoxidation[3]. Oxidative damage occurs as a consequence of imbalance between the formation and inactivation of oxygen free radicals. Inactivation and removal of ROS depend on relations with antioxidative defense mechanism. Oxidative damage leads to the destruction of membrane lipids and production

* Corresponding author:

hossameldin.mo62@gmail.com (Omar HM)

Published online at http://journal.sapub.org/diabetes

Copyright (C) 2012 Scientific \& Academic Publishing. All Rights Reserved of lipoperoxides and their products[4].

$\alpha$-lipoic acid is a disulfide compound that functions as a coenzyme in puruvate dehydrogenase and $\alpha$-ketoglutarate dehydrogenase mitochondrial reactions, leading to production of cellular energy. $\alpha$-lipoic acid reduce oxidative stress by scavenging a number of free radicals in both membrane and aqueous domains by preventing membrane lipid peroxidation and protein damage through the redox regeneration of other antioxidants such as Vit $\mathrm{C}$ and $\mathrm{E}$ and by increasing intracelular GSH[5\&6]. Moreover, $\alpha$ lipoic acid improves the imbalance between increased oxidative stress and delpeted antioxidant defense even in patients with poor glycemic control and albuminuria[7].

$\mathrm{N}$-acetyl cysteine is a small molecule containing a thiol group. In addition to its antioxidant properties, has the capacity to inhibit several inflammatory elements related to oxidative stress[8]. It prevents short-term hyperglycemiainduced insulin resistance in vivo[9], counteracting ethanolinduced oxidative stress[10] and has heptoptroective actions in chronic inflammatory liver disease which mediated partially through the modulation of nitric oxide produc- 
tion[11].

In this study we aimed to determine the effects of $\alpha$ lipoic acid and $\mathrm{N}$-acetyl cysteine on the oxidative stress parameters in plasma and hepatic tissue and the hepatic morphological changes of diabetic rabbits induced by alloxan.

\section{Materials and Methods}

\section{i- Animals and experiment design}

Thirty two healthy male white rabbits of poskit strain with body weight average 800-1200 g were purchased from the farm of Faculty of Agriculture, Assiut University, Assiut, Egypt. They were housed in the animal house of the Zoology Department, Faculty of Science, Assiut University in wooden cages in groups of five rabbit per cage and were kept in a room temperature with normal light/dark cycle. Rabbits given commercial concentrated fodder: crude protein $17 \%$. crude fat $2.63 \%$ and energy $2500 \mathrm{kcal}$ (Al-wagh Alkbli company, Abnob, Assiut, Egypt) and water ad labitum through the study period. All experimental protocols held on animals were done according to regulations set by the Institutional Animal Care and approved by Assiut University.

\section{ii- Experimental design}

After adaptation in the Animal House of Zoology Department for one week, the rabbits were randomly divided into two categories. The first contain 8 rabbits work as control group injected with a single dose of distilled water (1 $\mathrm{ml} /$ rabbit, i.p.). The second category treated animals contain 24 rabbits were injected with a single dose of alloxan (180 $\mathrm{mg} / \mathrm{kg}$ body weight, i.p.)[12]. Then after three weeks (onset of type 1 diabetes) the rabbits were divided into three groups

- The first treated : was left as positive diabetic rabbits

- The second treated: was injected with $\alpha$-lipoic acid (100 mg/kg body weight, i.p.) daily for 7 days.

- The third treated: was injected with $\mathrm{N}$-acetyl cysteine (100 mg/kg body weight, i.p.) daily for 7 days.

- All animals were injected in similar volume injections

All experimental protocols held on animals were done according to regulations set by the Institutional Animal Care and approved by Assiut University.

\section{ii- Samples collection}

After the experimental period the animals were killed for collection of blood and liver was excised immediately, washed in ice cold saline. A portion of the liver was immediately utilized for histological and immunohistochemistry for iNOS. The reminder of liver was immersed in nitrogen and stored in $-20{ }^{\circ} \mathrm{C}$ and used for further studies. A $10 \%$ homogenate of liver was prepared in phosphate buffer (0.1M, pH 7.2).

\section{iii- Biochemical measurements}

Plasma glucose level was determined by enzymatic colorimetric method by using commercial kits (Diamond Diagnostics Company, Egypt) according to Trinder[13]. ALT activity in plasma was assayed by commercial kit (Spectrum Dianostics, Egypt) according to Young[14].

A total protein was measured by the method of Lowry et al.[15]. Nitric oxide was measured as nitrite concentration coloimetrically by the method of Ding et al.[16]. Lipid peroxides as thiobarbituric acid reactive substances was determined according to the method of Ohkawa et al.[17]. Carbonyl protein was determined as described by Stadtman and Levine[18]. Measurement of DNA fragmentation was based on the hydrolysis of DNA leading to release of free deoxyribose that was colorimetrically measured at $575 \mathrm{~nm}$ after reaction with the dipenylamine reagent according to KuritaOchiai et al.[19]. Superoxide dismutase activity was determined according to its ability to inhibit the autoxidation of epinephrine at alkaline medium according to Misra and Fridovich[20]. Catalase activity was estimated by procedure of Luck[21], basing on its ability to decompose $\mathrm{H}_{2} \mathrm{O}_{2}$. Glutathione S-transferase activity was assayed using 1-chloro2,4-dinirtobenzene as substrate according to the method of Habig et al.[22]. $\gamma$-glutamyl transpeptidase activity was determined by the method of Meister et al.[23] using $\gamma$ glutamyl p-nitroanilide as substrate. The activity of glutathione peroxidase was assayed by the method of Mohandas et al.[24]. Glutathione reductase activity was determined by the method of Carlberg and Mannervik[25]. Glutathione was determined using the method of Beutler et al.[26]. Vit E was measured using Emmerie-Engel reaction based on the reduction of ferric to ferrous ions forming a red complex with $\alpha, \alpha$-dipyridyl according to the method of Roe[27].

\section{iv- Histological Studies}

Pieces of liver was quickly removed and fixed in 10\% neutral buffered formalin for histological investigations. Then sections $(7 \mu \mathrm{m})$ were mounted on slides and dried overnight at $37^{\circ} \mathrm{C}$. Sections were dewaxed in xylene and hydrated in a graded series of alcohols and stained with Harris hematoxylin and eosin according to Drury and Wallington[28]. For electron microscope small pieces fixed in $2.5 \%$ glutaraldehyde in cacodylate buffer, then washed in cacodylate buffer $(0.1 \mathrm{M}, \mathrm{pH} 7.2)$ and post fixed in $1 \%$ osmium tetroxide. Then placed in propylene oxide for 60 minutes, then in pure Epon 812 and incubated in a special polymerization incubator. Semithin section were cut at $1 \mu$ and stained with toluidine blue and examined for localization of the desired tissue and accordingly ultrathin sections were prepared. Sections were stained with uranyl acetate and lead citrate[29] and examined under transmission electron microscope (Jeol, 100CXII) operated at $80 \mathrm{KV}$, Electron Microscope Center of Assiut University).

\section{v- Statistical analysis}

The results were analyzed by one way analysis of variance (ANOVA) followed by Newman-Keuls Multiple Comparison Test as post- Test by using Prism program for windows, version 3.0 (Graph pad softwarwe, Inc., San Diago CA. USA). The significance difference between groups was accepted at $\mathrm{P}<0.05$. 


\section{Results}

The final body weights were lower in diabetic rabbits than in the control group (Table 1). The initial body weights (not shown) were similar in control and diabetic groups. The final body weights in $\alpha$-lipoic acid and $\mathrm{N}$-acetyl cysteine treated diabetic rabbits were higher than in the untreated diabetic group, but lower than control group. The relative weight of liver was increased in diabetic rabbits compared to the control group, however return to near nor- mal in $\alpha$-lipoic acid and $\mathrm{N}$-acetyl cysteine groups. Plasma glucose concentration and ALT activity were increased significantly in diabetic rabbits compared with the control group, and were significantly decreased by $\alpha$-lipoic acid and $\mathrm{N}$-acetyl cysteine treatment (Table 1).

Hepatic LPO, NO, CP and DNA fragmentation \% and plasma LPO and NO were significantly higher in diabetic rabbits compared with control group (Table 2). These increases were decline by $\alpha$-lipoic acid and $\mathrm{N}$-acetyl cysteine treatment $(\mathrm{P}<0.05$ vs. untreated diabetic groups).

Table 1. \% of change in rabbits weight and relative weight of liver and Mean Values \pm S.E.M. of plasma glucose and ALT activity of control and different treated rabbits

\begin{tabular}{|c|c|c|c|c|}
\hline Group & $\begin{array}{c}\text { \% of change in } \\
\text { Rabbits weight }\end{array}$ & $\begin{array}{c}\text { \% of change in rela- } \\
\text { tive weight of liver }\end{array}$ & $\begin{array}{c}\text { Plasma glucose } \\
\text { (mg/dl) }\end{array}$ & Plasma ALT activity (U/L) \\
\hline G1: Control & 37.28 & 2.95 & $120.44 \pm 7.25$ & $23.78 \pm 1.99$ \\
\hline G2: Diabetes & -17.73 & 4.39 & $351.20 \pm 37.88^{\mathrm{a}^{* * *}}$ & $38.36 \pm 2.97^{\mathrm{a}^{* * *}}$ \\
\hline G3: Diabetes+ $\alpha$-lipoic acid & 11.98 & 3.16 & $148.87 \pm 20.57^{\mathrm{w}^{* * *}}$ & $20.39 \pm 2.75^{\mathrm{b}^{* * *}}$ \\
\hline G4: Diabetes+ N-acetyl cysteine & 21.22 & 3.04 & $129.20 \pm 16.17^{\mathrm{b}^{* * *}}$ & $14.87 \pm 1.05^{\mathrm{b}^{* * *}}$ \\
\hline
\end{tabular}

$\mathrm{a}=$ significance difference between normal control group and diabetic group.

$\mathrm{b}=$ significance difference between diabetic group and $\alpha$-lipoic acid and N-acetyl cysteine and treated groups. ${ }^{*}=\mathrm{P}<0.05,{ }^{* *}=\mathrm{P}<0.01$ and ${ }^{* * *}=\mathrm{P}<0.001$

Table 2. Mean Values \pm S.E.M. of Lipid peroxidation (LPO), nitric oxide (NO), Carbonyl proteins (CP) levels and DNA fragmentation \% in the plasma and liver of control and different treated rabbits

\begin{tabular}{|c|c|c|c|c|c|c|}
\hline \multirow[t]{2}{*}{ Biomarker } & \multicolumn{2}{|c|}{$\begin{array}{c}\text { LPO } \\
\text { (nmol MDA/mg protein) }\end{array}$} & \multicolumn{2}{|c|}{$\begin{array}{c}\text { NO } \\
\text { (nmol nitrite/mg protein) }\end{array}$} & \multirow{2}{*}{$\begin{array}{c}\text { CP } \\
\text { (nmol/mg protein) } \\
\text { Liver } \\
\end{array}$} & \multirow{2}{*}{$\begin{array}{c}\text { DNA Fragmentation } \\
\%\end{array}$} \\
\hline & Plasma & Liver & Plasma & Liver & & \\
\hline G1: Control & $0.18 \pm 0.02$ & $0.55 \pm 0.4$ & $0.82 \pm 0.1$ & $4.02 \pm 0.36$ & $13.21 \pm 1.52$ & $25.65 \pm 3.17$ \\
\hline G2: Diabetes & $0.53 \pm 0.08^{\mathrm{a}^{* * * *}}$ & $1.43 \pm 0.07^{\mathrm{a}^{* * *}}$ & $1.49 \pm 0.09^{\mathrm{a}^{* *}}$ & $6.04 \pm 061^{\mathrm{a}^{*}}$ & $20.59 \pm 2.32^{\mathrm{a}^{*}}$ & $39.32 \pm 3.21^{\mathrm{a}^{*}}$ \\
\hline G3: Diabetes $+\alpha$-lipoic acid & $0.28 \pm 0.04^{\mathrm{b}^{* *}}$ & $1.06 \pm 0.17^{\mathrm{b}^{*}}$ & $0.82 \pm 0.11^{\mathrm{b}^{* *}}$ & $4.61 \pm 46^{\mathrm{b}^{*}}$ & $14.09 \pm 2.01^{\mathrm{b}^{*}}$ & $24.01 \pm 4.31^{\mathrm{b}^{*}}$ \\
\hline G4: Diabetes+ N-acetylcysteine & $0.31 \pm 0.05^{\mathrm{b}^{* *}}$ & $1.06 \pm 0.08^{\mathrm{b}^{*}}$ & $1.10 \pm 0.05^{\mathrm{b}^{*}}$ & $4.41 \pm 0.33^{\mathrm{b}^{*}}$ & $13.43 \pm 1.49^{b^{*}}$ & $28.71 \pm 3.70^{\mathrm{b}^{*}}$ \\
\hline
\end{tabular}

$\mathrm{a}=$ significance difference between normal control group and diabetic group.

$\mathrm{b}=$ significance difference between diabetic group and $\alpha$-lipoic acid and N-acetyl cysteine treated groups. $*=\mathrm{P}<0.05, * *=\mathrm{P}<0.01$ and $* * *=\mathrm{P}<0.00$

Table 3. Mean Values \pm S.E.M. of glutathione (GSH) and vitamin E (Vit E) levels in the plasma and liver of control and different treated rabbits.

\begin{tabular}{|c|c|c|c|c|}
\hline \multirow{2}{*}{ Biomarker } & \multicolumn{2}{|c|}{ GSH $(\mu \mathrm{g} / \mathrm{mg}$ protein) } & \multicolumn{2}{|c|}{ Vit E $(\mu \mathrm{g} / \mathrm{mg}$ protein) } \\
\cline { 2 - 5 } & Plasma & Liver & Plasma & $5.20 \pm 0.51$ \\
\hline G1: Control & $0.32 \pm 0.12$ & $2.34 \pm 0.18$ & $1.19 \pm 0.22$ & $2.39 \pm 0.33^{\mathrm{a}^{* * *}}$ \\
\hline G2: Diabetes & $1.34 \pm 0.12^{\mathrm{a}^{* * *}}$ & $1.52 \pm 0.11^{\mathrm{a}^{*}}$ & $0.44 \pm 0.04^{\mathrm{a}^{* * *}}$ & $6.09 \pm 0.22^{\mathrm{b}^{* * *}}$ \\
\hline G3: Diabetes+ $\alpha$-lipoic acid & $0.68 \pm 0.13^{\mathrm{b}^{*}}$ & $2.46 \pm 0.43^{\mathrm{b}^{*}}$ & $1.09 \pm 0.22^{\mathrm{b}^{*}}$ & $4.40 \pm 0.42^{\mathrm{b}^{* * *}}$ \\
\hline G4: Diabetes+ N-acetylcysteine & $0.86 \pm 0.11^{\mathrm{b}^{*}}$ & $2.68 \pm 0.17^{\mathrm{b}^{*}}$ & $1.87 \pm 0.12^{\mathrm{b}^{* * *}}$ & \\
\hline
\end{tabular}

$\mathrm{a}=$ significance difference between normal control group and diabetic group.

$\mathrm{b}=$ significance difference between diabetic group and $\alpha$-lipoic acid and $\mathrm{N}$-acetyl cysteine and treated groups. $*=\mathrm{P}<0.05, * *=\mathrm{P}<0.01$ and $* * *=\mathrm{P}<0.001$

Table 4. Mean Values \pm S.E.M. of Catalase (CAT), Superoxide dismutase (SOD), Glutathione reductase (GR), Glutathione peroxidase (GPx), Gluathione S-Transferase (GST), and $\gamma$-glutamyl trasnspeptidase (GGT) activities in the plasma and liver of control and different treated rabbits

\begin{tabular}{|c|c|c|c|c|c|}
\hline \multicolumn{2}{|l|}{ Biomarkers } & G1 Control & G2 Diabetes & G3 Diabetes $+\alpha$-lipoic acid & G4 Diabetes+ N-acetylcysteine \\
\hline \multirow{2}{*}{$\begin{array}{c}\text { CAT } \\
(\mathrm{U} / \mathrm{min} / \mathrm{mg} \text { protein }\end{array}$} & Plasma & $0.82 \pm 0.22$ & $1.65 \pm 0.21^{\mathrm{a}^{*}}$ & $1.03 \pm 0.24^{\mathrm{b}^{*}}$ & $0.88 \pm 0.14^{\mathrm{b}^{*}}$ \\
\hline & Liver & $92.28 \pm 9.81$ & $131.99 \pm 13.88^{\mathrm{a}^{*}}$ & $90.14 \pm 1.36^{\mathrm{b}^{*}}$ & $66.79 \pm 8.07^{b^{* *}}$ \\
\hline \multirow{2}{*}{$\begin{array}{c}\text { SOD } \\
\text { (U/min/mg protein) }\end{array}$} & Plasma & $0.28 \pm 0.04$ & $0.15 \pm 0.02^{\mathrm{a}^{*}}$ & $0.28 \pm 0.05^{\mathrm{b}^{*}}$ & $0.30 \pm 0.03^{b^{*}}$ \\
\hline & Liver & $4.42 \pm 0.76$ & $2.57 \pm 0.31^{\mathrm{a}^{*}}$ & $4.81 \pm 0.78^{\mathrm{b}^{*}}$ & $4.96 \pm 0.39^{\mathrm{b}^{*}}$ \\
\hline \multirow{2}{*}{$\begin{array}{c}\text { GR } \\
\text { (U/min/mg protein) }\end{array}$} & Plasma & $0.08 \pm 0.01$ & $0.11 \pm 0.01^{\mathrm{a}^{*}}$ & $0.08 \pm 0.01^{\mathrm{b}^{*}}$ & $0.08 \pm 0.01^{\mathrm{b} * *}$ \\
\hline & Liver & $1.33 \pm 0.16$ & $1.86 \pm 0.11^{\mathrm{a}^{*}}$ & $1.29 \pm 0.15^{\mathrm{b}^{*}}$ & $1.07 \pm 0.16^{\mathrm{b}^{* *}}$ \\
\hline \multirow{2}{*}{$\begin{array}{c}\mathrm{GPx} \\
\text { (U/min/mg protein) }\end{array}$} & Plasma & $0.09 \pm 0.02$ & $0.16 \pm 0.01^{\mathrm{a}^{* *}}$ & $0.12 \pm 0.01^{\mathrm{b}^{*}}$ & $0.10 \pm 0.01^{\mathrm{b}^{* *}}$ \\
\hline & Liver & $0.33 \pm 0.06$ & $1.01 \pm 0.08^{\mathrm{a}^{* * *}}$ & $0.81 \pm 0.04^{\mathrm{b}^{*}}$ & $0.64 \pm 0.07^{\mathrm{b}^{* *}}$ \\
\hline \multirow{2}{*}{$\begin{array}{c}\text { GST } \\
\text { (nmol/min/mgprotein) }\end{array}$} & Plasma & $4.11 \pm 0.83$ & $6.44 \pm 0.21^{\mathrm{a}^{*}}$ & $4.87 \pm 0.53$ & $5.85 \pm 0.56$ \\
\hline & Liver & $37.39 \pm 3.21$ & $49.22 \pm 2.37^{\mathrm{a}^{*}}$ & $39.82 \pm 2.97^{\mathrm{b}^{*}}$ & $37.02 \pm 3.23^{\mathrm{b}^{*}}$ \\
\hline \multirow{2}{*}{$\begin{array}{c}\text { GGT } \\
\text { (nmol/min/mgprotein) }\end{array}$} & Plasma & $0.66 \pm 0.08$ & $0.37 \pm 0.05^{\mathrm{a}^{*}}$ & $0.80 \pm 0.13^{b^{*}}$ & $0.74 \pm 0.11^{\mathrm{b}^{*}}$ \\
\hline & Liver & $22.41 \pm 1.181$ & $16.21 \pm 1.03^{\mathrm{a}^{*}}$ & $26.84 \pm 1.76^{\mathrm{b} * * *}$ & $21.31 \pm 1.76^{\mathrm{b}^{*}}$ \\
\hline
\end{tabular}

$\mathrm{a}=$ significance difference between normal control group and diabetic group.

$\mathrm{b}=$ significance difference between diabetic group and $\alpha$-lipoic acid and N-acetyl cysteine and treated groups. ${ }^{*}=\mathrm{P}<0.05, * *=\mathrm{P}<0.01$ and $* * *=\mathrm{P}<0.001$ 

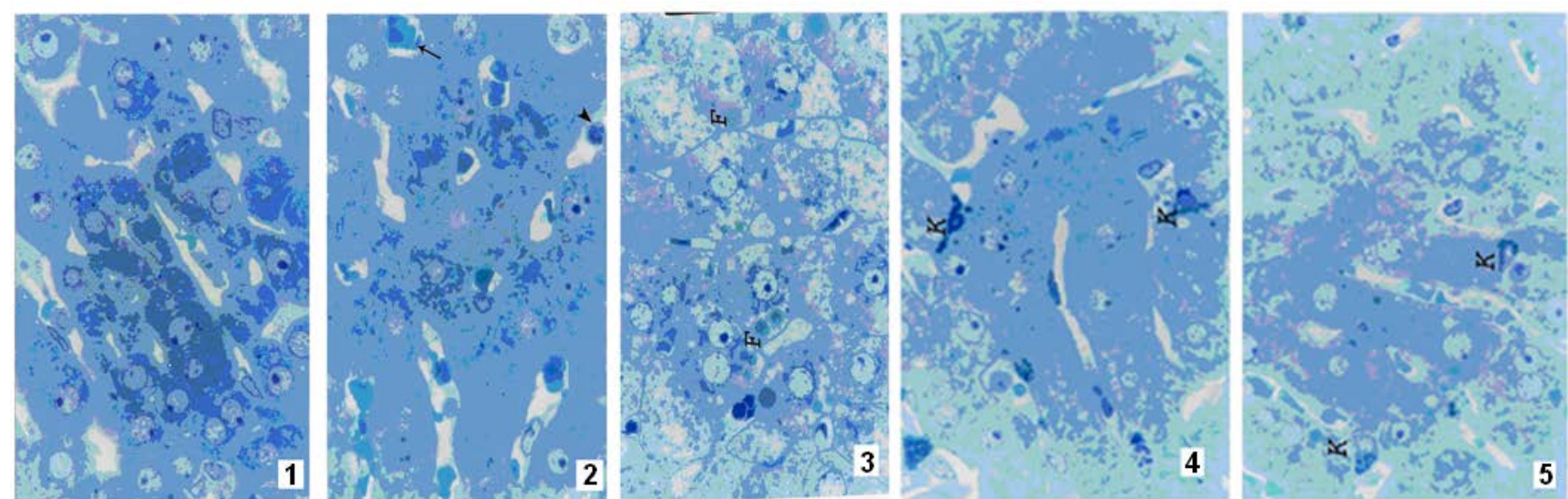

Figure 1-5.
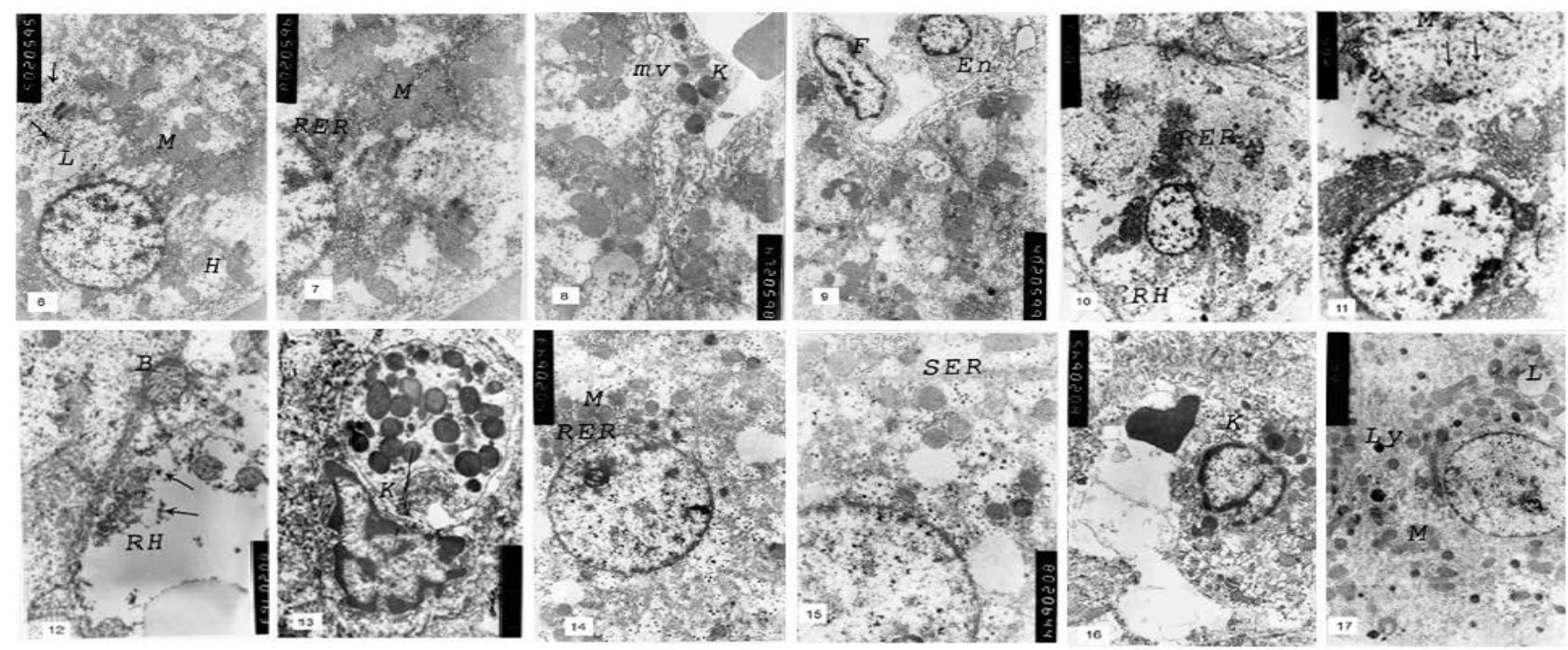

Figure 6-17.

Hepatic GSH concentration was significantly decreased (34\%) in diabetic rabbits compared with the control group (Table 3), and this decrease was overcorrected by $\alpha$-lipoic acid (61\%) and $\mathrm{N}$-acetyl cysteine (70\%) versus untreated diabetic group. However, in plasma GSH was significantly increased (318\%) in diabetic rabbits compared with the control group, and this increase was reduced by $\alpha$-lipoic acid (49\%) and $\mathrm{N}$-acetyl cysteine (41\%) versus untreated diabetic rabbits. Vit $\mathrm{E}$ concentration was significantly increased in plasma $(\mathrm{P}<0.01)$ and in hepatic tissue $(\mathrm{P}<0.001)$ compared with the control group (Table 3 ). This decreased was overcorrected in plasma and tissue by $\alpha$-lipoic acid and $\mathrm{N}$-acetyl cysteine treatment (145\% and 309\% respectively) and in hepatic tissue by a-lipoic acid treatment (150\%) versus untreated diabetic rabbits.

CAT, GR, GPx and GST activities were significantly increased $(\mathrm{P}<0.05)$, however, SOD and GGT activities were decreased $(\mathrm{P}<0.05)$ in plasma and hepatic tissues of diabetic rabbits compared with the control group (Table 4). The previous alternation in the enzymatic antioxidant activities were overcorrected by $\alpha$-lipoic acid and $\mathrm{N}$-acetyl cysteine treatment versus untreated diabetic rabbits.

Examination of semithin sections in the liver of control rabbits showed that the hepatic cell plates are radiating from central vein. Blood sinusoids separate the plates from each others with uniform distribution of cell organelles (Fig. 1). After alloxan treatment, dilated and congested blood sinusoids were observed (Fig. 2). Hydropic degenerative changes were observed in the hepatocytes with multiple fat droplets. The cellular organelles are densely packed against a background of less densely stained cytoplasmic matrix (Fig.3). After $\alpha$-lipoic acid treatment, an improvement in the dilatation and congestion of the blood sinusoids with multiple observed Kupffer cells (Fig. 4) was shown. However, after $\mathrm{N}$-acetyl cysteine treatment, normal architecture of liver was observed apart from excess Kupffer cells in comparison to control (Fig. 5).

Semithin section image of normal rabbits liver showing hepatic cell plates radiating from central vein. Blood sinusoids separate the plate from each others. Note the uniform distribution of cell organelles (Fg1), congested blood sinusoids. Note the RBCs (arrow) and WBCs (arrow head) in the sinusoids (Fig2), hydropic degenerative changes in the hepatocytes with multiple fat droplets (F), cellular organelles are densely packed against a background of less densely stained cytoplasmic matrix (Fig 3). The liver of 
diabetic rabbits treated with $\alpha$-lipoic acid showing an improvement in the dilatation and congestion of the blood sinusoids with multiple observed Kupffer cells (K) (Fig 4) and the liver of diabetic rabbits treated with $\mathrm{N}$ acetylcyseine showing normal architecture apart from excess Kupffer cells (K) in comparison to control (Fig5). (Toluidine blue X1000)

The hepatocyte of control rabbits appears with characteristic rounded euchromatic nucleus and uniformly distributed organelles in the cytoplasm. Glycogen rosettes and lipid droplets are observed. Some areas of hyaloplasm are visible (Figs. 6\&7). Microvilli are observed between the surfaces of two hepatocytes and abutting on the perisinusoidal space whereas the Kupffer cell and fat storing cell are present. Blood sinusoid with endothelial linning is observed (Figs. 8\&9). After alloxan treatment, a small sized nucleus of hepatocyte with a perinuclear aggregation of RER cisternae, however it is not observed in the peripheral cytoplasm. The number of mitochondria in the hepatocyte was reduced with wide areas of rarefied hyaloplasm (Fig. 10). A large amount of glycogen rosettes and multiple microbodies were clearly observed in some hepatocytes (Fig. 11). Other hepatocytes showed wide part of cytoplasm largely devoid of organelles and amorphous material could be detected within the rarefied hyaloplasm (Fig. 12). Kupffer cell was present in the perisinusoidal space with irregular heterochromatic nucleus and large number of phagosomes that were surrounded by a well delineated membrane (Fig. 13). After $\alpha$-lipoic acid treatment, an improvement in the amount of mitochondria and RER, their distribution was more or less similar to those in the control. Also large amount of glycogen rosettes and multiple SER were detected (Figs. 14\&15). Kupffer cell with irregular heterochromatic nucleus and few phagosomes was observed in the perisinusoidal space (Fig. 16). After N-acetyl cysteine treatment, the hepatocytes appeared more or less similar to control (Fig. 17).

Electron micrograph of the liver of normal rabbits showing uniformly distributed mitochondria in the cytoplasm. Some areas of hyaloplasm $(\mathrm{H})$ are visible. Mitochondria (M), RER, glycogen rosettes (arrow) and lipid droplets (L) are observed (Fig6 X5000). A magnified part of the previous figure showing groups of mitochondria separated by RER cisternae (Fig7 X8000) Also, in the liver of normal rats, Microvilli (mv) are observed between the surfaces of two hepatocytes and abutting on the perisinusoidal space and Kupffer cell (K) in that space (Fig8 X6700), Fat storing cell $(\mathrm{F})$ in the perisinusoidal space and endothelial lining of capillary (En) (Fig9 X8000). Electron micrograph of the liver of diabetic rabbits showing a small sized nucleus of hepatocyte with a perinuclear aggregation of RER cisternae while it is not observed in the peripheral cytoplasm. Number of mitochondria was reduced in the hepatocyte with wide areas of rarefied hyaloplasm (RH) (Fig10 X2700). A large amount of glycogen rosettes (arrow) and multiple microbodies (M) (Fig11 X6700). A wide part of cytoplasm was largely devoid of organelles, amorphous material (ar- row) within the rarefied hyaloplasm ( $\mathrm{RH})$ and bile canaliculi (B) were observed between the surfaces of two hepatocytes (Fig12 X8000). Kupffer cell (K) with irregular heterochromatic nucleus and containing a large number of phagosomes that were surrounded by a well delineated membrane Fig13 X10000). In diabetic rabbits treated with $\alpha$-lipoic acid liver showed an improvement in the amount of mitochondria (M) and RER, their distribution was more or less similar to those in the control (Fig14 X5000), Large amount of glycogen rosettes and multiple SER (Fig15 X8000), Kupffer cell (K) with irregular heterochromatic nucleus and containing few phagosomes (Fg16 X8000). And in diabetic rabbits treated with $\mathrm{N}$-acetylcysteine liver showed the hepatocyte appeared more or less similar to control. Lipid (L), lysosomes (Ly) and mitochondria (M) were observed (Fig17 X4000).

\section{Discussion}

The present results of plasma glucose and ALT activity in alloxan-induced diabetic rabbits (Table 1) are consistent with the finding in rats[30\&31], in mice[32] and in rabbits[33]. The increment of ALT activity may be mainly due to the leakage of this enzyme from the hepatocyte cytosol into the blood stream[34], which gives an indication on the hepatotoxic effect of alloxan. Treatment of diabetic rabbits with $\alpha$-lipoic acid or $\mathrm{N}$-acetyl cysteine for 7 days restores the above parameters to their normal levels. However, myrtle oil which has anti-hyperglycemic effect failed to restore the elevated ALT activity in alloxan diabetic rabbits[35]. In the present work rabbits treated with alloxan after 4 weeks showed marked weight loss and increased relative liver weight. These results are consistent with previous reports in alloxan-induced diabetes in rabbits[36] and in rats[37]. The increase in liver weight is possibly due to the infiltration of the organ by fatty tissue[38]. Ectopic fat depositions in peripheral tissue can precede diabetes and could occur with the development of glucose intolerance and insulin resistance[39].

Islet cell death during the development of diabetes by alloxan is thought to be mediated by ROS. Alloxan is selectively accumulated in $ß$ cells through uptake via the glucose transporter in the plasma membrane. In the presence of GSH alloxan generates ROS in a cyclic reaction between GSH and its reduction product, dialuric acid[12\& 40]. The highly reactive hydroxyl radical, which is one of the ROS generated in this process, is considered to be responsible for the formation of carbonyl groups in protein leading to loss of thiol groups[41\&42]. The present results together with previous findings (40\&43) indicate that ROS generated by alloxan contributes to the ß-cell toxicity and hyperglycemia. $\alpha$-lipoic acid or $\mathrm{N}$-acetyl cysteine treatment significantly reduced hyperglycemia in diabetic group, by a mechanism that is independent on insulin, because antioxidant treatments were started after ß-cell damage. In this point, Odetti et al. [44] reported that any protection of pancreatic ß-cells 
against STZ by the antioxidants is considered improbable. Moreover, $\alpha$-lipoic acid increase glucose uptake through recruitment of the glucose transporter-4 to plasma membrane with insulin-stimulated glucose uptake[45\& 46]. Similarly, N-acetyl cysteine treatment increased glucose uptake in individuals exposed to high glucose[9].

Apoptosis can be considered as a finely regulated mechanism to maintain the genome stability of multicellular organisms by eliminating cells with severe DNA damage caused by oxidative stress[47]. DNA fragmentation is considered as an indication of apoptosis[48]. In the present study, alloxan elevated significantly DNA fragmentation in liver (Table 2). In this point, hyperglycemia induced by glucose administration for few hours leads to DNA fragmentation similar to apoptosis in some organs of rats[49]. The interpretation of the increased DNA fragmentation may be due to hyperglycemia, which increased endogenous glyceraldehydes and $\mathrm{H}_{2} \mathrm{O}_{2}$ levels, which have strongest ability to damage DNA[50\&51]. In the present study, $\alpha$-lipoic acid or $\mathrm{N}$-acetyl cysteine significantly counteracted hyperglycemia and elevated DNA fragmentation (Table 2). $\alpha$-lipoic acid decreases DNA fragmentation in alloxan-induced diabetic rabbits through the enhancement of glucose uptake resulting in normoglycemia and scavenging intracellular superoxides improving mitochondrial function and DNA damage[9]. Moreover, N-acetyl cysteine has the ability to reduce apoptosis in kidney[44]. Extracellular thiols may be important for the inhibition of apoptosis because DNA fragmentation was inhibited by physiologically low levels of L-cysteine[52].

ROS metabolism is disrupted in diabetes and animal models of diabetes[53\&54]. Oxidative stress biomarkers are indicative of damages to carbohydrates, lipids and proteins by ROS[54]. It has been established in mammalian system that direct damage to proteins or chemical modification of amino acids in proteins during oxidative stress can give rise to protein carbonyls[55]. In the present study, CP was significantly increased in hepatic tissues of diabetic rabbits (Table. 2). Elevation of carbonyl protein in hepatic tissue of diabetic rabbits was reported by[36]. The significance of hepatic complications in diabetes may rise due to the glycosylation of protein resulting in numerous alterations in hepatic ultra structures as seen in the present study[56]. The present data showed that treatment of diabetic rabbits with $\alpha$-lipoic acid or $\mathrm{N}$-acetyl cysteine significantly reduced CP. In consistence with these data Bitar et al.[57] found that $\alpha$ lipoic acid ameliorated the diabetes related defects in glucose metabolism, protein oxidation as well as the activation by insulin of the various steps of the insulin signaling pathway. The ability of $\alpha$-lipoic acid or $\mathrm{N}$-acetyl cysteine to reduce $\mathrm{CP}$ may be mediated by reduced hyperglycemia and oxidative stress through the recycling of reduced Vit $\mathrm{C}$ and GSH[58\&59].

Irreversible cell damage occurs when the cell is no longer able to maintain its GSH content[36]. Therefore, measurement of GSH in biological samples is important for the understanding of GSH homeostasis in disease[60]. In the pre- sent study, a significant decrease of GSH level was observed in hepatic tissue (Table. 3), which is in agreement with other authors[61\&62]. In this point, STZ-injection caused a rapid decrease in the GSH content of liver and pancreatic islets, however, the fall in islets was more pronounced and persistent[63]. The decrease in GSH content is probably due to ROS generation by alloxan and hyperglycemia[64]. In addition, GSH is extruded from cells undergoing apoptosis[65]. This finding is in harmony with the present results where GSH content is increased in plasma of diabetic rabbits (Table. 3 ). In the present work both $\alpha$-lipoic acid or N-acetyl cysteine restored the depleted GSH in diabetic rabbits (Table. 3). Similar finding was reported[9\&66] they found that $\alpha$-lipoic acid or $\mathrm{N}$-acetyl cysteine increases GSH. Lately, $\alpha$-lipoic acid or N-acetyl cysteine was reported to prevent disturbances in GSH homeostasis in blood and liver in alloxan-diabetic rabbits[67]. The increased GSH content in hepatic tissues of diabetic rabbits treated with $\mathrm{N}$-acetyl cysteine is due its role as a precursor of cysteine, which in turn enters in the GSH synthesis cycle[68].

The key indicator of GSH metabolism in an organ is the GGT, which initiates the catabolism of GSH by removing the $\gamma$-glutamyl group from GSH[69]. The present data showed a significant reduction in hepatic GGT activity of diabetic rabbits (Table. 4). The inhibition of GGT activity may lead to the inability of tissue to recover the constituent amino acids of GSH[[70]. So, the increased GGT activity that are observed in diabetic rabbits treated with $\alpha$-lipoic acid or $\mathrm{N}$-acetyl cysteine probably represents harmonizing mechanism to recover GSH to about its normal control level (Table. 4).

The reaction of ROS with membrane lipoproteins produces malondialdehyde[71]. The present data revealed that persistent hyperglycemia through alloxan treatment generated ROS attack produced a significant increase in LPO in hepatic tissue and plasma of diabetic rabbits than control (Table 2). Previous studies done on diabetic animals showed the same results[36\&72]. Elevated level of LPO is one of the characteristic features of chronic diabetes[73]. In diabetes fatty acid oxidation causing a marked proliferation of peroxisomes in hepatocytes that ultimately could be associated with the development of hepatocellular tumours[74]. In the present study, the administration of $\alpha$ lipoic acid or $\mathrm{N}$-acetyl cysteine to diabetic rabbits caused marked decrease in LPO level (Table 2). In this aspect, $\alpha$ lipoic acid inhibit LPO in the heart and skeletal muscle mitochondria of aged rats[75], Because it has an effective role as a scavenger of lipoperoxides at their mitochondrial source and preventing LPO[76]. Also, N-acetyl cysteine has a protective effect on pulmonary LPO[77].

GPx protect cells against LPO and shares the substrate, $\mathrm{H}_{2} \mathrm{O}_{2}$ with catalase[78]. It has been observed that GPx can be rapidly induced when cells are exposed to oxidative stress[79]. In agreement with other reports, the present study showed that the activity of CAT and GPx was higher in diabetic rabbits than normal[36\&80]. The selective cytotoxicity of alloxan to the $§$ cell results from the coincidence 
of two features: a rapid cellular uptake of the drug and an exquisite sensitivity to peroxide itself attributable to low peroxidase activity (GPx and CAT)[2]. Plasma GPx activity has been elevated in both types of diabetes[81]. The increased GPx activity is a consequence of increase in the pentose-phosphate pathway in the diabetic animals, because GPx utilizes GSH in the elimination of $\mathrm{H}_{2} \mathrm{O}_{2}$. Oxidized GSH thus formed requires NADPH for its subsequent reduction by GPx[82]. In the present study, it was found that $\alpha$-lipoic acid or $\mathrm{N}$-acetyl cysteine administration normalize the GPx and catalase in hepatic tissue and plasma of diabetic rabbits (Table 4). In this aspect, restoration of both CAT and GSH in vonadate-treated diabetic rats were observed[83].Moreover, vandate therapy could effectively normalize the GPx in diabetic rat[84].

Superoxide dismutase protects the organism against the deleterious effects triggered by the superoxide radical[82]. The present study showed a significant decrease in SOD activity in hepatic tissue and plasma of diabetic rabbits. This finding is in accordance with those previously described for SOD activity in the liver, kidney, spleen, heart, testis, pancreas, skeletal muscle and erythrocytes in alloxan or STZ induced diabetes in rats $(85,86 \& 87]$. The reduction in SOD activity may be due to the direct damaging effect of free radicals on the enzyme[88]. In this respect, SOD treatment can protect in vivo and/or in vitro against the high toxic potential of the superoxide radicals in alloxan-induced diabetic rats[89\&90]. $\alpha$-lipoic acid or $\mathrm{N}$ acetyl cysteine administration to diabetic rabbits restored the SOD activity to that of normal control. Similar result was obtained in intestine and adrenal cortex by treatment of STZ-induced diabetes in rats with insulin or GSH[91]. In addition, SOD acts prophylactically against alloxaninduced diabetes in mice[89].

Additionally, activation of polyol pathway by hyperglycemia can diminish NADPH available for GR and may cause a significant decrease in GSH level[36]. In the present study, GR activity was increased in hepatic tissue and plasma of diabetic rabbits. GR activity was reduced after 3 weeks in liver of STZ-treated rats[92]. In contrary, GR activity not changed in hepatic tissue of rat which suggested that GR may not be involved in protection against STZinduced diabetes[84\&93]. GST is localized in hepatocytes and in proximal tubule cells, which are the main cells responsible for the most rapid GSH turnover in liver. In the present study, alloxan-induced diabetes in rabbits caused a significant increase in the GST activity in hepatic tissue and plasma compared to that of normal control. The increase in GST activity indicates the apparent stress in terms of increased concentration of cellular metabolites[94].

In the present study, the decreased Vit E level in hepatic tissue and plasma of diabetic rabbits compared to that of the control animals was observed (Table 3). Hepatic Vit E was decreased in rats with STZ-induced diabetes of 20 weeks duration[95]. Deficiency of Vit E may result from increased its consumption due to increased oxidative stress associated with hyperglycemia[96]. The demand for the Vit E in dia- betes is increased[97]. Currently, the molecular and cellular effects of Vit $\mathrm{E}$ have been explained either by acting as a mere antioxidant preventing damage to membranes and regulating their activity by specifically scavenging ROS[98], or by interacting and regulating specific enzymes and transcription factors influencing cellular structures[99]. In the present study $\alpha$-lipoic acid or $\mathrm{N}$-acetyl cysteine treatment of diabetic rabbits restored the Vit E content to that of normal control. It has been observed that $\alpha$-lipoic acid prevented the consequences of Vit $\mathrm{E}$ deficiency in rats[100], due to its ability to react with free radicals which are prooxidants for Vit $\mathrm{C}$ and $\mathrm{E}[66]$. Vit E primarily being oxidized to tocopheroxyl radical and then being reduced back to tocopherol by GSH[101]. So, treatment of the diabetic rabbits with $\mathrm{N}$-acetyl cysteine restored the Vit $\mathrm{E}$ content to that of normal control. Combination of Vit $\mathrm{E}$ and $\alpha-$ lipoic acid may provide protection against apoptosis[102].

NO is a multifunctional biomolecule involved in a variety of physiological and pathological processes. A large amount of NO is toxic to the host and causes several diseases such as apoptosis and diabetes[103]. The present study showed that NO was significantly increased in hepatic tissue and plasma of diabetic rabbits (Table 2). NO synthase dependent reactivity was impaired in blood vessels during diabetes[104]. Endothelium dependent relaxation was enhanced after STZ-induced diabetes in renal artery[105]. NO synthase activity is a pathogenic factor in diabetes development. So, administration of NO synthase inhibitor largely suppressed the development of hyperglycemia following STZ treatment in mice[106]. Moreover, NO mediates the inhibitory effects of cytokines on glucose stimulated insulin secretion by human islets[107]. During the development of experimental diabetes the inhibitory serotoninergic effect may be mediated by the NO pathway[108]. In the present study, the level of NO was reverted back to near normal in liver and plasma by treatment of diabetic rabbits with $\alpha$-lipoic acid or $\mathrm{N}$-acetyl cysteine. $\alpha$-lipoic acid inhibits NO synthesis during endotoxemia in rats by down regulating NOS expression[109]. N-acetyl cysteine has a protective effect by reducing iNOS expression via diminishing LPO[110]. Moreover, N-acetyl cysteine might have protective actions in chronic inflammatory liver disease, mediated partially through the modulation of NO production[111].

The observed degenerative changes in the hepatocytes might occur as a result of glycated effected of hyperglycemia on the proteins thus explained the diabetic changes in the subcellular organelles of liver. These results are in accordance with the work of Myint et al.[112] who found that in diabetic conditions liver proteins are more susceptible to glycation than other tissue proteins. However, the inducing effects of hyperglycemia on ROS as well as LPO result in cellular damage as well as apoptotic changes. $\mathrm{N}$-acetyl cysteine treatment improved dilatation in the blood capillaries as well as reduced aggregation of Kupffer cells that were observed in excess in diabetic animals. Kupffer cells may have a role in the removal of debris in degenerated tissues 
and may play a role in the production of ROS after their activation. In rheumatoid arthritis, the production of ROS from activated macrophages are inhibited by the gold (I)containing compounds that induce cellular antioxidative stress genes[113\&114]. In the present study, the observed reduction in Kupffer cells following the administration of $\alpha$-lipoic acid or $\mathrm{N}$-acetyl cysteine might confirm the potential role of these activated cells in the manifestation of oxidative stress in diabetic rabbits. In conclusion: oxidative stress in alloxan induced diabetic rabbits plays a crucial role in hepatic degenerative changes. Treatment of diabetic rabbits with $\alpha$-lipoic acid or $\mathrm{N}$-acetyl cysteine caused normoglycemia and liver cell reprogramming due to its antioxidant activities. Beneficial action seems to result mainly from direct scavenging of ROS and restoring GSH redox state.

\section{REFERENCES}

[1] Davis, J.L.; Mendiratta, Jr.S and May J.M. (1998): Similarities in the metabolism of alloxan and dehydroascorbate in human erythrocytes. Biochem. Pharmacol., 55:1301-1307.

[2] Malaisse, W.J.; Malaise-Lagae, F.; Sener, A. and Pipeleers, D.G. (1982): Determinants of the selective toxicity of alloxan to the pancreatic ß cell. Proc. Natl. Acad. Sci. USA, 79: 927-930.

[3] Wolf, G.; Chen, S. and Ziyadeh, F. N. (2005): Perspectives in diabetes from the periphery of the glomerular capillary wall toward the center of disease podocyte injury comesofage in diabetic nephropathy. Diabetes, 54: 1626-1634.

[4] Khansari, N.; Shakiba, Y. and Mahmoudi, M. (2009): Chronic inflammation and oxidative stress as a major cause of age- related diseases and cancer. Recent Patents on Inflammation \& Allergy Drug Discovery, 3, 73-80 73

[5] Evans, J.L. and Goldfine, I.D. (2000): $\alpha$-Lipoic acid: a multi-functional antioxidant that improves insulin sensitivity in patients with type II diabetes. Diab. Technol.Therap., 2:401413.

[6] Packer,L.; Witt, E.H. and Tritscher, H.J.(1995): Alpha-lipoic acid as a biological antioxidant. Free Radic. Biol. Med., 19:227-250.

[7] Borcea, V.; Nourooz-Zadeh, J.; Wolff, S.P.; Klevesath, M.; Hofmann, M.; Urich, H.; Wahl, P.; Ziegler, R.; Tritschler, H.; Halliwell, B. and Nawroth, P.P. (1999): $\alpha$-lipoic acid decreases oxidative stress even in diabetic patients with poor glycemic control and albuminuria. Free Radic. Biol. Med., 26: $1495-1500$.

[8] Blesa, S.; Cortijo, J.; Mata, M.; Serrano, A.; Closa, D.; Santangelo, F.; Estrela, J.M.; Suchankova, J. and Morcillo, E.J. (2003): Oral N-acetyl cysteine attenuates the rat pulmonary inflammatory response to antigen. Eur. Respir. J., 21: 394400.

[9] Haber, C.A.; Lam, T.K.T.; Yu, J.Z.; Gupta, N.; Goh, T.; Bogdanovic, E.; Giacca, A. and Fantus, I.G. (2003): $N$ acetylcysteine and taurine prevent hyperglycemia-induced insulin resistance in vivo: possible role of oxidative stress. Am. J. Physiol., 285: 744-753.

[10] Wang, A.L.; Wang, J.P.; Wang, H.; Chena, Y.H.; Zhao, L.; Wang, L.S.; Wei, W. and Xu, D.Z. (2006): A dual effect of $\mathrm{N}$-acetyl cysteine on acute ethanol-induced liver damage in mice. Hepat. Res., 34: 199-206.

[11] Majanol, P.L.; Medina, J.; Zubı'a, I.; Sunyer, L; Lara-Pezzi, E.; Guez A.M.; Lo'pez-Cabrera, M. and Moreno-Otero, M. (2004): N-Acetyl cysteine modulates inducible nitric oxide synthase gene expression in human hepatocytesq. J. Hepatology, 40: 632-637.

[12] Szkudelski, T. (2001): The Mechanism of alloxan and streptozotocin action in ß cells of the rat pancreas. Physiol. Res., 50: 536-546.

[13] Trinder, P. (1969): Quantitative determination of glucose using the GOP-PAP method. Clin. Biochem., 6: 24-27.

[14] Young, D. S. Ed., Effects of drugs on clinical laboratory tests. 3rd ed. Washington, DC: AACC Press, 1990.

[15] Lowry, O. H.; Rosebrough, N. J.; Farr, A. L. and Randall, R.J. (1951): Protein measurement with the Folin phenol reagent. J. Biol. Chem., 41:1863-1870.

[16] Ding, A. H.; Nathan, C. F. and Stuchr, D. J. (1988): Release of reactive nitrogen intermediate and reactive oxygen intermediate from mouse peritoneal macrophages. Comparison of activating cytokines and evidence for independent production. J. Immunol., 141:2407-2412.

[17] Ohkawa, H.; Ohishi, N. and Yagi, K. (1979): Assay for lipid peroxides in animal tissue by thiobarbaturic acid reaction. Anal. Biochem., 95: 351-358.

[18] Stadtman, E. R. and Levine, R. L. (2000): Protein oxidation. Ann. NY Acad. Sci., 899: 191-208.

[19] Kurita-Ochiai, T.; Fukushima, K. and Ochiai, K. (1999): Lipopolysaccharide stimulates butyric acid- induced apoptosis in human blood mononuclear cells. Infect. Immun., 67(1): 22-29.

[20] Misra, H. P. and Fridovich, I. (1972): The role of superoxide anion in the autoxidation of epinephrine and a simple assay for superoxide dismutase. J. Biol. Chem., 247: 3170-3175.

[21] Luck, H., Catalase in: Bergmer H-U, Ed., Methods of enzymatic analysis. Academic Press, New York, pp. 885-888, 1963.

[22] Habig, W. H.; Pabst, M. J. and Jokoby, W. B. (1974): Glutathion s-transferase. J. Biol. Chem., 249: 7130-7139.

[23] Meister, A.; Tate, S.S. and Griffith, O.W. (1981): Gammaglutamyl transpeptidase. Methods in Enzymology, 77: 237253.

[24] Mohandas, M.; Marshall, J.J.; Duggin, GG.; Horvath, JS. and Tiller, D. (1984): Differential distribution of glutathione and glutathione related enzymes in rabbit kidney. Cancer Res., 44: 5086-5091.

[25] Carlberg, L. and Mannerick, B. (1975): Glutathione level in rat brain. J.Biol.Chem., 250:4575-4580.

[26] Beutler, E.; Duron, O. and Kelly, B. M. (1963): Improved method for the determination of blood glutathione. J. Lab. Clin. Meth., 61: 882-888. 
[27] Roe, J. H. Standard methods of clinical chemistry. Vol. 3 edited David Selgson Acad. Press. New York, p. 35, 1961.

[28] Drury, R. A. B. and Wallington, E. A. Carletion's histological technique. Oxford. New York. Toronto. Oxford University Press, 1980.

[29] Johannessen, J. Instruction and techniques in electron microscopy in human medicine. Mchqraw-Hill Int.Book.Co, 1978.

[30] Campos, K.E.; Diniz, Y.S.; Cataneo, A.C.; Faine, L.A.; Alves, M.J. and Novelli, E.L. (2003): Hypoglycaemic and antioxidant effects of onion, Allium cepa: dietary onion addition, antioxidant activity and hypoglycemic effects on diabetic rats. Internat. J. Food Sci. Nutr., 54 (3): 241-246.

[31] El-Demerdash, F.M.; Yousef, M.I. and Abou El-Naga, N.I. (2005): Biochemical study on the hypoglycemic effects of onion and garlic in alloxan-induced diabetic rats. Food Chem. Toxicol., 43: 57-63.

[32] Kumar, G.R. and Reddy, K.P. (1999): Reduced nociceptive responses in mice with alloxan induced hyperglycemia after garlic (Allium sativum) treatment. Indian J. Exp. Biol., 37: 662-666.

[33] Jain, R.C. and Vyas, C.R. (1975): Garlic in alloxan-induced diabetic rabbits. Amer. J. Clin. Nutr., 28: 684-685.

[34] Navarro, C. M.; Montilla, P. M.; Martin, A.; Jimenez, J. and Utrilla, P.M. (1993): Free radicals scavenger and antihepatotoxic activity of Rosmarinus. Plant Medicine, 59: 312-314.

[35] Sepici, A., Gurbuz, I., Cevik, C., Yesılada, E. (2004): Hypoglycaemic effects of myrtle oil in normal and alloxandiabetic rabbits. J. of Ethnopharm., 93: 311-318.

[36] Gumieniczek, A. (2005): Effects of repaglinide on oxidative stress in tissues of diabetic rabbits. Diabetes Res. Clin. Pract. 68 (2): 89-95.

[37] Sailaja Devi, M.M. and Das, U.N. (2006): Effect of prostaglandins against alloxan-induced diabetes mellitus. Prostagl. Leukotri. Essent. Fat. Ac., 74: 39-60.

[38] Ugochukwu, N.H. and Figgers, C.L. (2007): Dietary caloric restriction improves the redox status at the onset of diabetes in hepatocytes of streptozotocin-induced diabetic rats. Chemico-Biolo. Interact., 165: 45-53.

[39] Rasouli, N.; Raue, U.; Miles, L.M.; Lu, T.; Di Gregorio, G.B.; Elbein, S.C. and Kern, P.A. (2005): Pioglitazone improves insulin sensitivity through reduction in muscle lipid and redistribution of lipid into adipose tissue. Am. J. Physiol., 288: 930-934.

[40] Elsner, M.; Gurgul-Convey, E. and Lenzen, S. (2006): Relative importance of cellular uptake and reactive oxygen species for the toxicity of alloxan and dialuric acid to insulinproducing cells. Free Radic. Biol. Med., 41: 825-834.

[41] Oliver, C.N., (1987): Inactivation of enzymes and oxidative modification of proteins by stimulated neutrophils. Arch. Biochem. Biophys., 253: 62-72.

[42] Bainy, A.C.D.; Saito, E.; Carvello, P.S.M. and Junqueira, V.B.C. (1996): Oxidative stress in gill, erythrocytes, liver and kidney of Nile tilapia (Oreochromis niloticus) from a polluted site. Aquat. Toxicol., 34: 151.

[43] Kubisch, H. M.; Wang, J.; Bray, T. M.; Phillips, J. P. (1997):
Targeted overexpression of $\mathrm{Cu} / \mathrm{Zn}$ superoxide dismutase protects pancreatic $ß$ cells against oxidative stress. Diabetes, 46: 1563-1566.

[44] Odetti, P.; Pesce, C.; Traverso, N.; Menini, S.; Maineri, E. P.; Cosso, L.; Valentini, S.; Patriarca, S.; Cottalasso, D.; Marinari, U. M. and Pronzato, M. A. (2003): Comparative trial of $\mathrm{N}$-acetyl cysteine, taurine, and oxerutin on skin and kidney damage in long-term experimental diabetes. Diabetes, 52: 499-505.

[45] Packer, L., Kraemer, K., and Rimbach, G. (2001): Molecular aspects of lipoic acid in the prevention of diabetes complications. Nutrition, 17: 888-895.

[46] Holmquist, L.; Stuchbury, G.; Berbaum, K.; Muscat, S.; Young, S.; Hager, K.; Engel, J. and Münch, G. (2007): Lipoic acid as a novel treatment for Alzheimer's disease and related dementias. Pharmacol. Therap., 113: 154-164.

[47] Hall, A.G. (1999): The role of glutathione in the regulation of apoptosis. Eur. J. Clin. Invest., 29: 238- 245.

[48] Tanuma, S. Apoptosis: Cell Survival or Death. Tokyo, Japan, University of Tokyo Press, pp 1-25, 1994.

[49] Powell, L.A.; Nally, S.M.; McMaster, D.; Catherwood, M.A. and Trimble, E.R. (2001): Restoration of glutathione levels in vascular smooth muscle cells exposed to high glucose conditions. Free Radic. Biol. Med., 31: 1149-1155.

[50] Brownlee, M. (2001): Biochemistry and molecular cell biology of diabetic complications. Nature, 414: 813-820.

[51] Murata, M.; Mizutani, M.; Oikawa, S.; Hiraku,Y. and Kawanishi, S. (2003): Oxidative DNA damage by hyperglycemia-related aldehydes and its marked enhanceme nt by hydrogen peroxide. FEBS Lett., 554: 138-142.

[52] Yamamasu, S.; Sato, E.; Ogita, S. and Inoue, M. (1997): Role of glutathione metabolism and apoptosis in the regression of liver hemopoiesis. Free Radic. Biol. Med., 23(1): 100-109.

[53] Loven, D. P. and Oberley, L. W. Free radicals, insulin action and diabetes. In: Superoxide Dismutase, volume III Pathological States. Edited by Oberley, L.W., CRC Press, Inc. Boca Raton, Florida USA, PP. 152-189, 1985.

[54] Miyata, H.; Aozasa, O.; Ohta, S; Chang, T. and Yasuda, Y. (1993): Estimated daily intakes of PCDDs, PCDFs and nonortho coplanar PCBs via drinking water in Japan. Chemosphere, 26: 1527.

[55] Zusterzeel, P. L. M.; Rutten, H.; Roelefs, H. M. J.; Peters, W.H.M. and Steegers, E.A.P. (2001): Protein carbonyls in decidua and placenta of pre-eclamptic women as markers of oxidative stress. Placenta, 22: 213-219.

[56] Hunt, J. V.; Dean, R. T. and Wolff, S. P. (1988): Hydroxyl radical production and autoxidative glycosylation. Glucose autoxidation as the cause of protein damage in the experimental glycation model of diabetes mellitus and ageing. Biochem. J., 256: 205.

[57] Bitar, M.S.; Wahid, S.; Pilcher, C.W. Al-Saleh, E. and AlMulla, F. (2004): Alpha-lipoic acid mitigates insulin resistance in Goto-Kakizaki rats. Horm. Metab. Res., 36: 542549.

[58] Packer, L. (1998): Alpha-lipoic acid: a metabolic antioxidant 
which regulates NF-kappa B signal transduction and protects against oxidative injury. Drug Metab. Rev., 30: 245-275.

[59] Evans; J.L.; Goldfine, I.D.; Maddux, B.A. and Grodsky, G.M. (2003): Are oxidative stress-activated signaling pathways mediators of insulin resistance and $\beta$-cell dysfunction? Diabetes, 52:1-8.

[60] Pastore, A.; Federici, G.; Bertini, E. and Piemonte, F. (2003): Analysis of glutathione: Implication in redox and detoxification. Clin. Chim. Acta, 333: 19-39.

[61] Dincer, Y.; Aldemir, Z.; IIkova, H. and Akcay, T. (2002): Susceptibility of glutathione and glutathione related antioxidant activity to hydrogen peroxide in patients with type II diabetes: Effect of glycemic control. Clin. Biochem., 35: 295-301.

[62] Obrosova, I.G.; Fathallah, L.; Liu, E. and Nourooz-Zadeh, J. (2003): Early oxidative stress in the diabetic kidney: Effect of DL- $\alpha$-lipoic acid. Free Radic. Biol. Med., 34(2): 186-195.

[63] Oguzhan, B.; Yilmaz, M.T.; Memisoglu, K.; Ferendeci, N.; Biyikh, M.; Karaaslan, N.; Civelek, V.; Arioglu, E.; Dinccag, N. and Buyukdevrim, S. (1993): Tissue glutathione content in streptozotocin diabetes: a proposal to explain the specificity of STZ action. Med. Sci. Res., 21: 29-30.

[64] Stevens, M.J. (2005): Redox-based mechanisms in diabetes. Antioxid. Redox Signal., 7: 1483-1485.

[65] Kwon, Y-W.; Masutani, H.; Nakamura, H.; Ishii, Y. and Yodoi, J. (2003): Redox regulation of cell growth and cell death. Biol. Chem., 384: 991-996.

[66] Arivazhagan, P.; Juliet, P. and Panneerselvam, C. (2000): Effect of Dl- $\alpha$-lipoic acid on the status of lipid peroxidation and antioxidants in aged rats. Pharmacol. Res., 41 (3): 299303.

[67] Winiarska, K.; Malinska, D.; Szymanski, K.; Dudziak, M. and Bryla, J. (2007): Lipoic acid ameliorates oxidative stress and renal injury in alloxan diabetic rabbits. Bioch., 90: 450459.

[68] Fiordaliso, F.; Bianchi, R. and Staszewsky, L. (2004): Antioxidant treatment attenuates hyperglycemia-induced cardiomyocyte death in rats. JMOI Cell Cardiol., 37: 959-968.

[69] Ballatori, N.; Jacob, R.; Barrett, C. and Boyer, J.L. (1988): Biliary catabolism of glutathione and differential reabsorption of its amino acide constituents. Am. J. Physiol., 254: 17.

[70] Griffith, O.W. and Meister, A. (1980): Excretion of cysteine and gamma glutamylcysteine in human and experimental gamma glutamyl transpeptidase deficiency. Proc. Natl. Acad. Sci. USA, 77: 3384-3387.

[71] Kaviarasan, K.; Arjunan, M. M. and Pugalendi, K. V. (2005): Lipid profile, oxidant-antioxidant status and glycoprotein components in hyperlipidemic patients with/without diabetes. Clin. Chim. Acta, 362: 49-56.

[72] Afshari, A.T.; Shirpoor, A.; Farshid, A.; Saadatian, R.; Rasmi, Y.; Saboory, E.; Ilkhanizadeh, B. and Allameh A. (2007): The effect of ginger on diabetic nephropathy, plasma antioxidant capacity and lipid peroxidation in rats. Food Chem., 101: 148-153.

[73] Chaudhry, J.; Ghosh, N. N.; Roy, K. and Chandra, R. (2007):
Antihyperglycemic effect of a new thiazolidinedione analogue and its role in ameliorating oxidative stress in alloxaninduced diabetic rats. Life Sci., 80: 1135-1142.

[74] Sakuma, S.; Gotoh, K.; Sadatoku, N.; Fujita, T. and Fujimoto, Y. (2004): Effects of antirheumatic gold compounds on the conversion of xanthine dehydrogenase to oxidase in rabbit liver cytosol in vitro. Life Sciences, 75:1211-1218.

[75] Savitha, S.; Tamilselvan, J.; Anusuyadevi, M. And Panneerselvam, C. (2005): Oxidative stress on mitochondrial antioxidant defense system in the aging process: Role of Dl- $\alpha-$ lipoic acid and L-carnitine. Clin. Chim. Acta, 355: 173-180.

[76] Biewenga, G.P.; Haenen, G.R. and Bast, A. (1997): The pharmacology of the antioxidant lipoic acid. Gen. Pharmacol., 29: 315-331.

[77] Akca, T.; Canbaz, H.; Tataroglu, C.; Caglikulekci, M.; Tamer, L.; Colak, T.; Kanik, A.; Bilgin, O. and Aydin, S. (2005): The effect of $N$-acetyl cysteine on pulmonary lipid peroxidation and tissue damage. J. Surg. Res., 129: 38-45.

[78] Mates, J. M.; Perez-Gomez, C. and Nunez de Castro, I. (1999): Antioxidant enzymes and human diseases. Clin. Biochem., 32: 595-603.

[79] Lu, D.; Maulik, N.; Moraru, I.I.; Kreutzer, D.L. and Das, D.K. (1993): Molecular adaptation of vascular endothelial cells to oxidative stress. Am. J. Physiol., 264: C715-C722.

[80] Coudray, C.F.; Rock, E.; Coudray, C.; Grzelkowska, K.; Braesco-Azais, V.; Dardevet, D. and Mazur, A. (1999): Lipid peroxidation and antioxidant status in experimental diabetes. Clin. Chim. Acta, 284: 31-43.

[81] Tribe, R.M. and Poston, L. (1996): Oxidative stress and lipids in diabetes: A role in endothelium vasodilator dysfunction. Vasc. Med., 1: 195-206.

[82] Pereira, B.; Costa Rosa, L.F.B.; Safi, D.A.; Bechara, E.J.H. and Curi, R. (1994): Superoxide dismutase, catalase and glutathione peroxidase activities in the lymphoid organs of diabetic rats. J. Endocrinol., 142: 161-165.

[83] Sekar, N.; Kanthasamy, A.; William, S.; Balasubramaniyan, N. and Govindasamy, S. (1990): Antioxidant effects of vanadate on experimental diabetic rats. Acta Diabetol. Lat., 27: 285-293.

[84] Saxena, A. K.; Srivastava, P.; Kale, R.K. and Baquer, N.Z. (1993): Impaired antioxidant status in diabetic rat liver. Effect of vanadate. Biochem. Pharmacol., 45: 539-542.

[85] Loven, D. P.; Schedl, H. P.; Wilson, H.; Daabes, T.T.; Stengink, L. D.; Diekus, M. and Oberley, L. W. (1986): Effect of insulin and oral glutathione on glutathione levels and superoxide dismutase activities in organs of rats with streptozotocin-induced diabetes. Diabetes, 35: 503-507.

[86] Meki, A. M. A. and Omar, H. M. (1997): Effect of garlic oil treatment as antioxidant on alloxan-induced diabetic rats. Bull. Egypt. Soc. Physiol. Sci., 17(1): 98-113.

[87] Kedziora-Kornatowska, K.Z.; Luciak, M. and Paszkowski (2000): Lipid peroxidation and activities of antioxidant enzymes in the diabetic kidney: Effect of treatment with angiotensin convertase inhibitors. JUBMS Life, 49: 303-307.

[88] Wohaieb, S.A. and Godin, D.V. (1987): Alterations in free radical tissue defense mechanism in streptozotocin-induced 
diabetes in rat. Diabetes, 36: 1014-1018.

[89] Grankvist, K.; Marklund S. L. and Taljedal I. B. (1981): Superoxide dismutase is a prophylactic against alloxan diabetes. Nature, 94: 158-160.

[90] Abdel-Rahman, M. S.; Elrakawy, F. I. and Iskander, F. A. (1992): Protection of $ß$ cells against the effect of alloxan. Toxicol. Lett., 63: 155.

[91] Loven, D. P.; Schedl, H. P.; Oberley, L. W.; Daabes, T. T. and Stengink, L. D. (1983): Cu-Zn superoxide dismutase levels are depressed in various organs of streptozotocindiabetic rats and restored by insulin or glutathione treatment. Fed. Proc. Fed. Am. Soc. Exp. Biol., 42: 504.

[92] Mukherjee, B.; Mukherjee, J.R. and Chatterjee, M (1994): Lipid peroxidation, glutathione levels and changes in glutathione-related enzyme activities in streptozotocin-induced diabetic rats. Immunol. Cell Biol., 72: 109-114.

[93] Omar, H. M.; Rosenblum, J. K.; Sanders, R. A. and Watkins III, J. B. (1998): Streptozotocin may provide protection against subsequent oxidative stress of endotoxin or streptozotocin in rats. J. Biochem. Molec. Toxicol., 12(3): 143-149.

[94] Thomas, H.; Schladt, L.; Knehr, M. and Oesch, F. (1989): Effect of diabetes and starvation on the activity of rat liver epoxide hydrolases, glutathione-S-transferases and peroxisomal beta-oxidation. Biochem. Pharmacol., 38: 4291-4297.

[95] Higuichi, Y. (1982): Lipid peroxides and $\alpha$-tocopherol in rat streptozotocin- induced diabetes mellitus. Acta Med. Okayama, 36: 165-175.

[96] Munteanu, A. and Zingg, J-M. (2007): Cellular, molecular and clinical aspects of vitamin $\mathrm{E}$ on atherosclerosis prevention. Molec. Aspects Med., 28: 538-590.

[97] Oberley, L.W.(1988): Free radicals and diabetes. Free Radic. Biol. Med., 5:113-124.

[98] Traber, M.G. and Atkinson, J. (2007): Vitamin E, antioxidant and nothing more. Free Radic. Biol. Med., 43(1): 4-15.

[99] Azzi, A. (2007): Molecular mechanism of $\alpha$-tocopherol action. Free Radic. Biol. Med., 43 (1): 16-21.

[100] [Rosenberg, H.R. and Culik, R. (1959): Effect of $\alpha$-lipoic acid on vitamin $\mathrm{C}$ and vitamin $\mathrm{E}$ deficiencies. Arch. Biochem. Biophys., 80: 86-93.

[101] Rahimi, R.; Nikfar, S.; Larijani, B. and Abdollahi, M. (2005): A review on the role of antioxidants in the management of diabetes and its complications. Biomed. Pharmaco-ther., 59: 365-373.

[102] Marsh, S.A.; Laursen, P.B.; Pat, B.K.; Gobe, G.C. and Coombes, J.S. (2005): Bcl-2 in endothelial cells is increased by vitamin $\mathrm{E}$ and alpha-lipoic acid supplementation but not exercise training. J. Mol. Cell Cardiol., 38 (3): 445-451.

[103] Gotoh, T. and Mori, M. (2006): Nitric oxide and endoplasmic reticulum Stress. Arterioscl. Thromb. Vasc. Biol.,
26:1439-1446.

[104] Mayhan, W.C. and Patel, K.P. (1998): Treatment with dimethylthiourea prevents impaired dilatation of the basilar artery during diabetes mellitus. Am. J. Physiol., 274: H1895H1901.

[105] Bhardwaj, R. and Moore, P.K. (1988): Increased vasodilator response to acetylcholine of renal blood vessels from diabetic rats. J. Pharm. Pharmacol., 40: 739-742.

[106] Kolb, H.; Kiesel, U.; Kroncke, K-D. and Kolb-Bachofen, V. (1991): Suppression of low dose streptozotocin induced diabetes in mice by administration of a nitric oxide synthase inhibitor. Life Sci., 49: 213-217.

[107] Corbett, J.A.; Sweetland, M.; Wang, J.L.; Lancaster, G.R. and McDaniel, M.L. (1993): Nitric oxide mediates cytokineinduced inhibition of insulin secretion by human islets of Langerhans. Proc. Natl. Acad. SCi. USA, 90: 1731-1735.

[108] Garcia, M.; Morán, A.; Martín, M. L.; Mariette Barthelmebs, M. and Román, L. S. (2006): The nitric oxide synthesis/pathway mediates the inhibitory serotoninergic responses of the pressor effect elicited by sympathetic stimulation in diabetic rats. Eur. J. Pharmacol., 537: 126-134.

[109] De Marco, V.G.; Bosanquet, J.P.; Rawlani, V.R. and Skimming, J.W. (2005): Lipoic acid decreases exhaled nitric oxide concentrations in anesthetized endotoxemic rats. Vasc. Pharma., 43: 404 -410.

[110] Ca glıkülekci, M.; Pata, C.; Apac, D.D.; Dirlik, M.; Tamer, L.; Yaylak, F.; Kanik, F. and Aydin, S. (2004): The effect of $\mathrm{N}$-acetyl cysteine (NAC) on liver and renal tissue inducible nitric oxide synthase (iNOS) and tissue lipid peroxidation in obstructive jaundice stimulated by lipopolysaccharide (LPS). Pharm. Res., 49: 227-238.

[111] Majanol, P.L.; Medina, J.; Zubia, I.; Sunyer, L.;Lara-Pezzi, E.; Guez, A.M; Lopez-Cabrera, M. and Moreno,-Otero, M. ( 2004): N-acetylcysteine modulates inducible nitric oxide synthase gene expression in human hepatocytes. J.Hepatology, 40:632-637.

[112] Myint, T.; Hoshi, S.; Ookawara, T.; Miyazawa, N.; Suzuki, K.; and Taniguchi, N. (1995): Immunological detection of glycated proteins in normal and streptozotocin-induced diabetic rats using anti hexitol-lysine IgG. Biochim.. Biophys. Acta, 1272: 73-79.

[113] Sakuma, S.; Gotoh, K.; Sadatoku, N.; Fujita, T. and Fujimoto, Y. (2004): Effects of antirheumatic gold compounds on the conversion of xanthine dehydrogenase to oxidase in rabbit liver cytosol in vitro. Life Science, 75:1211-1218.

[114] Kataoka, K.; Handa, H. and Nishizawa, M. (2001): Induction of cellular antioxidative stress genes through heterodimeric transcription factor Nrf2/Small Maf by antirheumatic gold (I) compounds. J. Biol. Chem., 276 (36): 34074-34081. 